Article

\title{
A GIS-Based Procedure for Landslide Intensity Evaluation and Specific Risk Analysis Supported by Persistent Scatterers Interferometry (PSI)
}

\author{
Silvia Bianchini *, Lorenzo Solari and Nicola Casagli \\ Earth Sciences Department, University of Firenze, Via La Pira 4, I-50121 Firenze, Italy; \\ lorenzo.solari@unifi.it (L.S.); nicola.casagli@unifi.it (N.C.) \\ * Correspondence: silvia.bianchini@unifi.it; Tel.: +39-055-275-7551 \\ Academic Editors: Roberto Tomás, Fabian Löw and Prasad S. Thenkabail \\ Received: 4 September 2017; Accepted: 19 October 2017; Published: 26 October 2017
}

\begin{abstract}
The evaluation of landslide specific risk, defined as the expected degree of loss due to landslides, requires the parameterization and the combination of a number of socio-economic and geological factors, which often needs the interaction of different skills and expertise (geologists, engineers, planners, administrators, etc.). The specific risk sub-components, i.e., hazard and vulnerability of elements at risk, can be determined with different levels of detail depending on the available auxiliary data and knowledge of the territory. These risk factors are subject to short-term variations and nowadays turn out to be easily mappable and evaluable through remotely sensed data and GIS (Geographic Information System) tools. In this work, we propose a qualitative approach at municipal scale for producing a "specific risk" map, supported by recent satellite PSI (Persistent Scatterer Interferometry) data derived from SENTINEL-1 C-band images in the spanning time 2014-2017, implemented in a GIS environment. In particular, PSI measurements are useful for the updating of a landslide inventory map of the area of interest and are exploited for the zonation map of the intensity of ground movements, needed for evaluating the vulnerability over the study area. Our procedure is presented throughout the application to the Volterra basin and the output map could be useful to support the local authorities with updated basic information required for environmental knowledge and planning at municipal level. Moreover, the proposed procedure is easily managed and repeatable in other case studies, as well as exploiting different SAR sensors in L- or X-band.
\end{abstract}

Keywords: landslides; intensity; specific risk; Persistent Scatterers Interferometry; GIS

\section{Introduction}

Landslide hazard and risk analyses are important steps for urban planning in government strategies, but they are often challenging tasks that require expertise and availability of multiple datasets $[1,2]$.

In the geo-hazard community, landslide risk is generally defined as a measure of the expected probability of a damaging event in a given area and it results from the product of three macro-factors: hazard, vulnerability and exposure of the elements at risk [3-5]. Hazard is the temporal and/or spatial likelihood (susceptibility) of a potentially damaging landslide, occurring within a given area; vulnerability is the degree of loss to specific elements within the area affected by the landslide event; and exposure is an intrinsic value referred to the location, characteristics and cost of the elements at risk [6]. The risk analysis, prior to risk management, is usually based on the computation of these sub-components [7]. 
The scientific literature about landslide risk estimation distinguishes the "expected degree of loss due to a landslide for a given category of elements at risk" (i.e., specific risk) from the "expected number of live lost, people injured, damage to property and disruption of economic activity" (i.e., total risk) $[3,8]$.

Overall, the generation of total or specific risk zonation maps for landslide studies and environmental designs still appears to be a difficult issue, especially at medium scale [3].

A wide variety of different approaches is available in the scientific literature for hazard, vulnerability and risk zonation mapping. General reviews and summaries of developed methods on the argument can be found, for instance, in Dai et al. [9], Fell et al. [2] and Van Westen et al. [3].

Landslide risk can be assessed qualitatively or quantitatively $[3,9,10]$. The choice of the method strongly depends on the scale of the analysis, as well as on the availability, quality and precision of input data $[9,11]$. The qualitative risk analysis exploits descriptive classes or rating scales to describe the magnitude of expected consequences of a potential phenomenon, usually by means of contingency matrices [7,12,13] or risk scoring [14]. Conversely, the Quantitative Risk Analysis (QRA) is based on numerical values of the probability, vulnerability and expected damages, and it results in a numeric estimation of the risk [15]. At site-specific scale, a QRA can be carried out by means of limit equilibrium analysis [9].

Recently, Geographical Information System (GIS) has become a practical and useful tool for the spatial analysis of natural hazard phenomena $[16,17]$ and it makes the landslide risk mapping scalable, computable over large areas and rapidly updatable.

Space-borne remote sensing techniques can support and enhance risk mapping by providing precise point-wise measurements of ground motions with wide area coverage that can be efficiently implemented in the risk maps generation-chain.

In the last decades, many advanced multi-temporal SAR (Synthetic Aperture Radar) interferometric techniques have been developed after the first PSInSAR algorithm patented by [18]. All the different multi-temporal interferometric processing approaches [19-21] are usually called Persistent Scatterer Interferometry (PSI) techniques.

PSI methods have been usually used for detecting and mapping slow-moving landslides at both local and regional scales [22,23] in order to perform back-monitoring [24,25], to better define boundaries within LIMs (Landslide Inventory Maps) [26], to identify the most critical sites [27,28], as well as to assess the state of activity and the intensity of landslides over wide areas [29-31].

Some recent works have been published on the use of satellite interferometric radar data for refining and assisting landslide susceptibility maps generation [32,33].

In this work, we propose a new approach for producing a qualitative map of "specific risk" at municipal scale, supported by the use of recent satellite PSI data acquired in 2014-2017, implemented in a GIS environment. In particular, PSI measurements are exploited for updating the LIM of the area and for the landslide intensity estimation needed for evaluating the vulnerability.

Our procedure is presented throughout the application to the Volterra basin and the results could be useful to support the local authorities with updated basic information required for environmental planning at municipal level.

\section{Methodology}

We propose a GIS-based methodology for computing the specific risk (Figure 1), supported by ground velocity information derived from PSI data that are used for LIM updating and landslides intensity evaluation. The specific risk, defined as the expected degree of loss resulting from a natural geo-hazard of a given intensity, is expressed as the product: $\mathrm{Rs}=\mathrm{H} \times \mathrm{V}(\mathrm{E}, \mathrm{I})$, where $\mathrm{H}$ is the landslide spatial hazard and $\mathrm{V}$ is the vulnerability that depends on the elements at risk type (E) and on the intensity (I) of the phenomenon [34].

The basic environmental data available for the study area are: geological map, relief and land use maps. 
Three pre-existing maps, i.e., the LIM (Landslide Inventory Map), the landslide hazard map of the whole Volterra municipality and the landslide intensity map of a portion of the municipality, are employed and enhanced throughout the procedure.

PSI data are exploited either for better defining the landslide boundaries, thus improving the LIM of the area by means of radar-interpretation, or for supporting the Intensity map (I) generation, necessary for next steps of the procedure. In particular, we rely on the mean yearly ground velocities measured along the satellite Line of Sight $\left(\mathrm{V}_{\mathrm{LOS}}\right)$ of each radar benchmark, purposely converted into mean yearly velocities estimated along the downslope direction ( $\left.\mathrm{V}_{\mathrm{SLOPE}}\right)$, according to some procedures already tested and used in scientific literature [23,26].

The Elements at risk map (E) is derived from a merge of the land use map with the database of structures and infrastructures at municipal scale and it includes a classification of properties and facilities exposed to risk according to their nature and functionality. The E map and the I map are combined by means of a contingency matrix (MATRIX 1) for providing the vulnerability map (V) of the study area.

Finally, the computation of the Specific Risk was produced using another contingency matrix (MATRIX 2) by combining the Vulnerability classes with the Hazard classes (Figure 1).

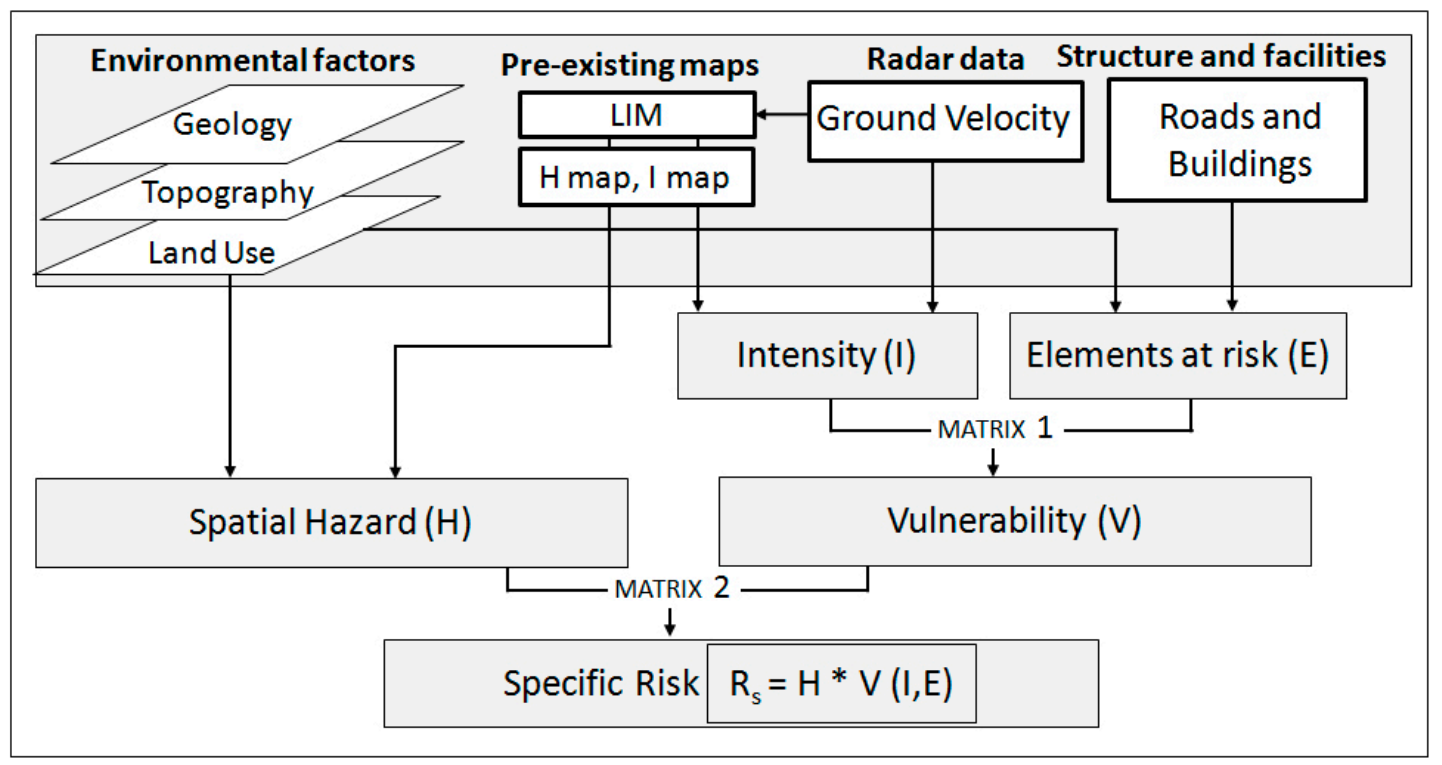

Figure 1. The work flowchart for the proposed landslide Specific Risk analysis.

\section{Study Area}

The study area, extending about $250 \mathrm{~km}^{2}$, is the Volterra municipality in Central Italy, and it comprises the Volterra basin between Era River valley and Cecina River valley.

The area is divided into two sub-basins, which belong to two different administrative Hydrogeological Setting Plans referred to a wider regional river basin (Arno River and Cecina River) (Figure 2a).

\subsection{Environmental Setting}

The environmental setting of the area is characterized by a hilly morphology with moderate relief and gentle slopes: the highest mountains are the Volterra tableland at $530 \mathrm{~m}$ above sea level (a.s.l.), Mt. Nero with an altitude of $508 \mathrm{~m}$ a.s.l., located NE of Volterra city, and Mt. Soldano (556 m a.s.l.) in the SE portion of the Volterra municipality (Figure 2).

The land-use map of the study area, derived from merging levels 2 and 3 of the CORINE Land Cover map published in 2000 and distributed by ISPRA (Istituto Superiore Protezione 
Ambiente-Environmental Protection Agency, Rome, Italy) shows that permanent crops and arable lands ("cropland") cover the $50 \%$ of the total area, while the land-use class defined as "agricultural/natural areas" (Figure 2a) [35]. Forests cover the $28 \%$ of the area and mainly occur in the southern and eastern sectors of the Volterra basin. Grassland and pasture, as well as sparse vegetation and scrubs, are scattered over the whole study area and represent, respectively, $7 \%$ and $8 \%$ of its spatial extension [17].

The most significant built-up zones ( $1 \%$ of the land use coverage map) are Volterra city sited in the center of the study area, and Saline di Volterra town in the southwestern portion (Figure 2a).

From a geological point of view, the Volterra basin is a wide Pliocene graben-basin, which is NW-SE oriented and bordered by normal faults [36]. This tectonic depression was generated during the Neogene post-orogenic extensional stage. The outcropping terrains are mainly Miocene-Pliocene clayey and sandy marine formations (respectively "Blue Clays" and "Villamagna sands") that represent the sedimentary filling of the basin. Calcarenites and limestones close the marine sedimentary succession and constitute the tableland on which Volterra city was built [37]. Fine and coarse detritic sediments (e.g., conglomerates and breccias), developed in lacustrine or lagoonal cycles or in a continental fluvial-deltaic environment are also present. Chemical sedimentary deposits, e.g., gypsum levels and travertine, crop out in the southern sectors of the area (e.g., on Saline di Volterra area), deriving from some Miocenic evaporitic episodes [38]. Along the margins towards SE of the basin, some underlying Jurassic-Cretaceous ophiolitic rocks, made of serpentinites, basalts and gabbros, sporadically outcrop. Marls and sandstones belonging to various sedimentary cycles also crop out in the eastern-southern portion of the municipality (Figure $2 b$ ). Recent colluvial and alluvial deposits finally fill the valleys incised by rivers and streams over the whole area [38].
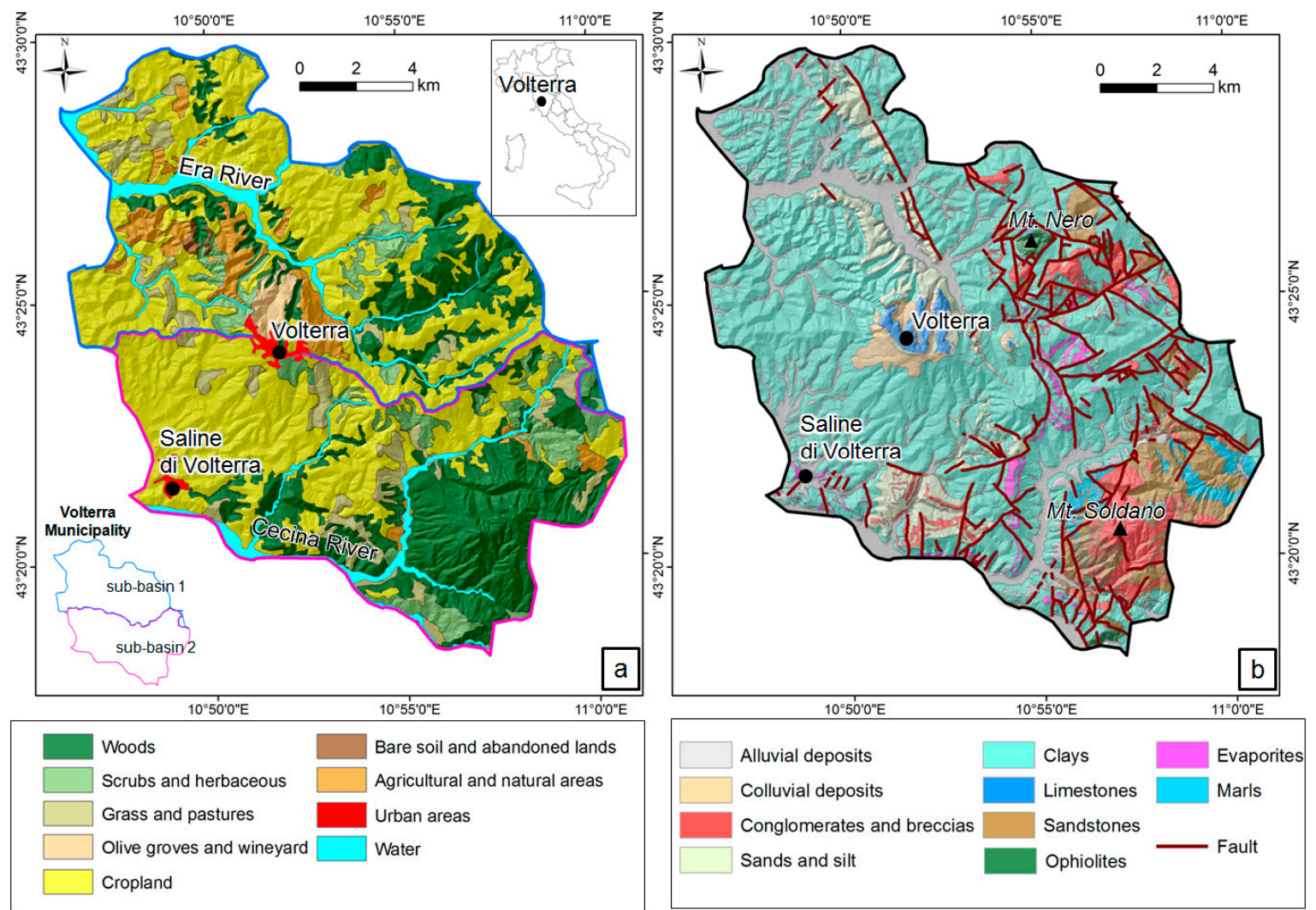

Figure 2. Environmental setting of the Volterra study area: (a) location of the Volterra municipality, sub-basins division and land cover map derived from Corine Land Cover map; and (b) geological map at the scale 1:50,000 from the Italian CARG Project [39]. Background layer is a DEM (Digital Elevation Model) with $20 \mathrm{~m}$ cell size extracted from TINITALY/01 DEM Project [40]. 


\subsection{LIM}

The geological setting and the topography of the Volterra municipality influence the spatial distribution and typology of the instability processes in the area, mainly represented by badlands and landslides.

Where clays crop out, i.e., in the southwestern portion of the study area, the morphology is gentle and widely affected by badlands, which are typical landforms of clayey soils due to erosional processes, and flows [37] (Figure 3a).

Landslides are widespread throughout the whole municipality. The most representative types are translational slides and complex phenomena. Some ground deformations are partially induced and maintained by gullying and slaking erosional processes of badlands. The colluvial and chaotic deposits, with thickness up to $20 \mathrm{~m}$, contribute to determine diffuse and shallow ground instability as surface soil creep [17,37].

The pre-existing information on landslides in the Volterra municipality relies on a landslide inventory provided by the Volterra municipality authority and dated back to 2010 [41] (Figure 3a).

\subsection{Radar Data}

In this work, we used space-borne ascending and descending Sentinel-1 SAR images acquired in microwave C-band (5.6 cm wavelength) in the time span 2014-2017 and processed with the SqueeSAR ${ }^{\mathrm{TM}}$ approach [42].

The SqueeSAR ${ }^{\mathrm{TM}}$ technique, which is an evolution of the PSInSAR ${ }^{\mathrm{TM}}$ approach [18], is based on the processing of the radar signals reflected from point-like deterministic objects with high signal-to-noise ratio (i.e., Persistent Scatterers (PS)) and from distributed scatterers (DS) that are extensive homogeneous areas (rural areas, pastures, bare soils, etc.), with lower back-scattered energy and moderate coherence, but anyway detectable from the background noise. The homogeneous areas that produce DS usually includes several pixels and single displacement time series assigned to each DS are estimated by averaging the time series of all pixels within the DS, effectively reducing noise in the data. The SqueeSAR ${ }^{\mathrm{TM}}$ basically ensures a significantly increased number of radar targets identified over the non-urbanized areas for ground measurement. Both DS areas and PS points converge to the PSI data as output of the SAR processing.

For each PSI radar benchmark, the geographic coordinates (latitude, longitude and elevation) with meter precision, the average LOS (Line Of Sight) velocity $\left(\mathrm{V}_{\mathrm{LOS}}\right)$ of the observation period with about $1 \mathrm{~mm}$ /year precision, and the displacement time series (i.e., LOS displacement at each acquisition) are available. The main features of the exploited PSI Sentinel-1 datasets are shown in Table 1.

The spatial distribution of $\mathrm{V}_{\text {LOS }}$ velocities of PSI data (Figure $3 b$ ) reveals that the PSI targets density is low, equal to $14 / \mathrm{km}^{2}$; this fact reflects the reflectivity characteristics of areas widely covered by crops and vegetation. The highest ground motion rates, up to about $15-20 \mathrm{~mm} /$ year, are recorded: (i) in the S-SW portion of Volterra city, corresponding to translational landslides involving Blue clays and shallow colluvial detritus; and (ii) in the N-NE portion of Saline di Volterra town, due to the extensive salt mining human activities in this area.

Table 1. Main features of PSI Sentinel-1 ascending and descending datasets in the study area.

\begin{tabular}{ccc}
\hline Geometry & Ascending & Descending \\
\hline Track angle $\left(^{\circ}\right)$ & 12.14 & 8.05 \\
Incidence angle $\left(^{\circ}\right)$ & 36.34 & 40.44 \\
Revisiting time $($ day) & 12 & 12 \\
Time span & 12 December 2014-12 May 2017 & 12 October 2014-17 May 2017 \\
$\mathrm{N}^{\circ}$ of used SAR images & 77 & 75 \\
$\mathrm{~N}^{\circ}$ of PSI data & 2786 & 4022 \\
\hline
\end{tabular}


Stable targets are displayed in a green color (Figure $3 b$ ). The stability threshold, in both descending and ascending tracks, is fixed at $\pm 2 \mathrm{~mm}$ /year, based on standard deviation values and on threshold choices already tested in scientific literature $[26,27,29]$. The increasing negative sign corresponds to a downward motion moving away from the sensor direction and it is displayed in yellow-red color range, while the positive sign stands for a movement towards the satellite and it is displayed in blue colors (Figure 3b).
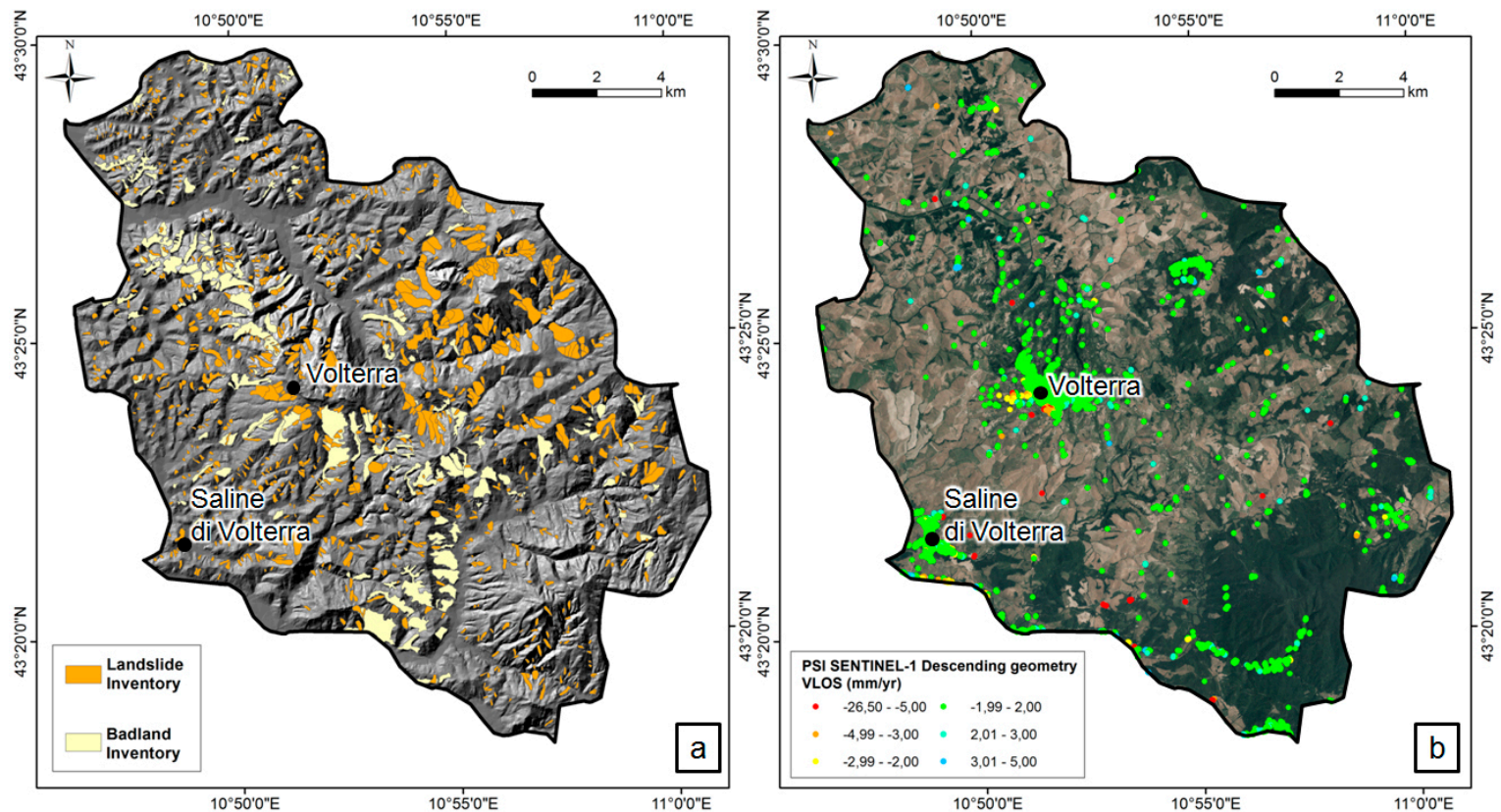

Figure 3. (a) Landslide inventory map and badland inventory maps. Background layer is a DEM (Digital Elevation Model) with $20 \mathrm{~m}$ cell size extracted from TINITALY/01 DEM Project [40]. The landslide inventory is derived from [37]; the badland inventory map is provided by Bianchini et al. (2016) [17]. (b) SENTINEL-1 PSI descending data (2014-2017) overlapped on orthophoto taken in 2013 and made available from Tuscany Region authority.

The LIM was improved and updated to a more recent setting thanks to the individuation of geomorphologic evidence related to landslide phenomena, using the visual analysis of digital color orthophotos (not stereo) at 1:2000 scale, taken in 2013 and made available from Tuscany Region and PSI measurements, relying on photo- and radar-interpretation procedures [27,29], as well as on some field surveys performed in 2014-2016.

In particular, the recorded $V_{\text {LOS }}$ velocities of PS data permitted to better verify or enlarge the landslide boundaries and evaluate their state of activity, while aerial imagery and field checks allowed tracing the present boundaries of slide movements and determining the typology of landslide movements. In total, 60 landslides were modified in boundaries with respect to the existing inventory that includes 1140 phenomena. Due to the low density of PSI data, it was possible to update the state of activity of only five landslides located nearby the urbanized area of Volterra and Saline di Volterra towns.

\subsection{Structure and Infrastructure}

The structure and infrastructure of the Volterra municipality are enclosed in a vector $\mathrm{db}$ (database), which includes liner elements and polygonal elements. The linear elements are railways and roads that are classified according to a hierarchical order in regional, county, local and private roads. The polygonal features correspond to all the buildings and facilities in the study area, classified based on their typology, provided by the municipal Land and Population Registry Office. 


\section{Specific Risk Analysis in the Study Area}

The Specific Risk of the Volterra municipality was computed by evaluating the landslide hazard, the landslide intensity and the vulnerability of the elements at risk within the study area [34]. These components and related maps were combined by means of contingency matrixes and led to the Specific Risk zonation of the study area.

\subsection{Susceptibility Map}

The landslide hazard is usually defined as the probability of occurrence of a potentially damaging phenomenon within a certain area and in a given period of time [8].

Thus, a landslide hazard zonation requires identifying those areas which could be affected by a damaging landslide and assessing the probability of landslide occurrence within a time span. However, the indication of a recurrence time for landslides is very difficult to determine, even under ideal conditions. As a result, landslide hazard is often represented by the landslide "susceptibility" [9]. The landslide susceptibility only identifies areas potentially affected by instability phenomena and does not imply an occurrence time for the events.

In our case study, we consider the term landslide "susceptibility" as we refer to the spatial likelihood of landslides occurrence without taking into account the temporal probability or return time [9]. The used susceptibility map of the study area was the one included within the strategic environmental Plan of the Volterra municipality and it was provided us by GEOPROGETTI Company [41].

The landslide susceptibility map is a raster map with $20 \mathrm{~m}$ cell resolution, compiled by GEOPROGETTI Company through a qualitative approach, by considering LIM and geomorphological and geological/lithological features (Figure 4). On hilly zones, morphology is the main predisposing factor, while, on low-gradient areas, litho-technical causes are predominant [37,41]. Five spatial hazard levels $(\mathrm{H} 0, \mathrm{H} 1, \mathrm{H} 2, \mathrm{H} 3$, and $\mathrm{H} 4$, sorted by increasing susceptibility level) are determined according to the Italian Regional guidelines (Law 1/2005 "Rules for the environmental management" and Law 94/1985 “Geological technical surveys for Urban Planning Support"), as summarized in Table 2 and Figure 4.

Table 2. Susceptibility (spatial hazard) classes according to the Italian Regional laws.

\begin{tabular}{cl}
\hline Hazard Class & \multicolumn{1}{c}{ Description } \\
\hline Class H0 & $\begin{array}{l}\text { Null/Very Low: geological features and natural processes are not } \\
\text { triggering factors for landslide events }\end{array}$ \\
\hline Class H1 & $\begin{array}{l}\text { Low: geological features and natural processes determine a low } \\
\text { susceptibility to landslide occurrences }\end{array}$ \\
\hline Class H2 & Medium: presence of naturally or o artificially stabilized landslides \\
\hline Class H3 & High: presence of dormant landslides and subsidence areas \\
\hline Class H4 & Very High: presence of active landslides and active erosional processes \\
\hline
\end{tabular}




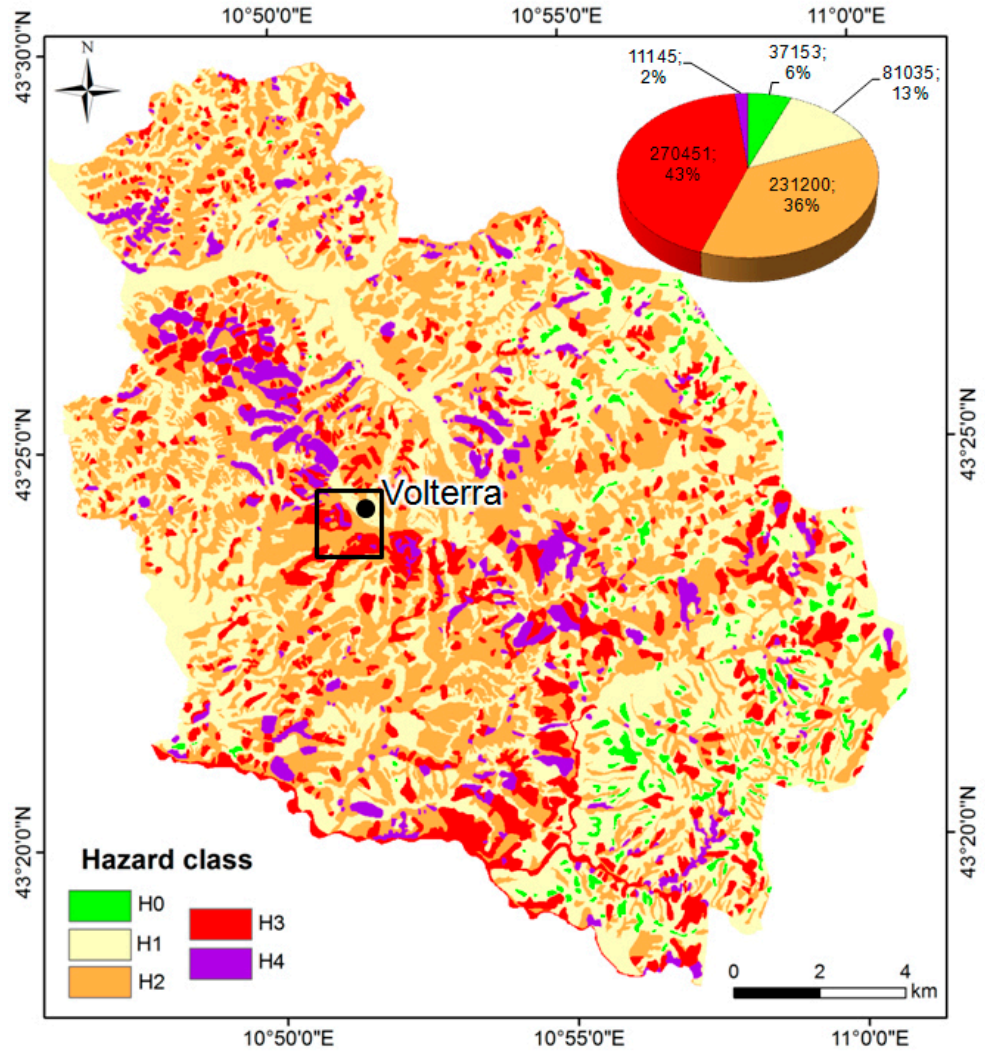

Figure 4. Susceptibility map after GEOPROGETTI [41]. The pie chart shows number of pixels and related percentage for each Susceptibility class. The box with black line shows the location of close-up area of Figure 5.

\subsection{Intensity Map}

The landslide intensity refers to the geometric or kinematic severity of a potentially dangerous or catastrophic phenomenon. The intensity of a landslide is a difficult parameter to be evaluated since many features can be accounted [2]. In the scientific literature, the intensity is usually considered depending upon potential consequences, velocity, volume, or kinetic energy (e.g., [43,44]). For instance, in Einstein et al. [45], the landslide intensity expresses the destructive power of the phenomenon associated with its spatial extent and its mechanical behavior. In Cardinali et al. [46], the landslide intensity is function of the volume of displaced material (in link with landslide depth) and of the expected velocity of the movement. Hungr [43] defines the intensity as the destructiveness of a landslide, in terms of energy, volume, area, depth, movement velocity or total displacement.

The assessment of the landslide intensity based on the possible consequent damages is not a proper choice, since it presumes the definition of the landslide intensity as an evaluation of the possible consequences (i.e., which is into the Risk definition). Conversely, it is better to a priori define the severity of the phenomenon without evaluating the expected consequences and by solely using the geometric or kinematic characteristics of the landslide.

Hungr $[47,48]$ proposes an intensity scale of landslides in terms of movement velocity and provides specific velocity thresholds associated with the different intensity classes. This intensity scale was also related to potential damages and modified by Cruden and Varnes [44] and then adopted by the IUGS/WGL [49].

At basin scale, the intensity is not easily measurable, due to the frequent lack of detailed information on volume and/or expected velocity for a large number of landslides [7]. 
In the Volterra municipality, we evaluated the intensity (I) of landslide hazard by means of two phases:

1. We produced a preliminary I raster map over the whole area. We here distinguished "known landslides", whose morphometry was known, and "no landslide areas".

The intensity value of "no landslide areas" was extracted from the existing intensity map of the sub-basin 1 (Arno River Basin) and extended to the sub-basin 2, published in Catani et al. [7], classified into five intensity classes based on a statistical analysis of the predisposing factors for slow-moving landslides. In particular, firstly we chose the predisposing factors that mainly influence volume and velocity, i.e., the lithology, the slope and the curvature of the area, and we joined them for the whole area (both sub-basins) by means of Overlay GIS operation, obtaining a map conventionally classified into three main combinations: flat areas with alluvial deposits almost without hazard; hilly areas, characterized by bare soils on terrigenous lithologies (e.g., clays, marls, flyshes) and most predisposed to hazard; the remaining area of Volterra municipality with intermediate predisposing condition. Then, this map was cross-compared with the existing intensity map of the sub-basin 1 [7], for finding out correspondence between the three conditions and intensity and extending them to the sub-basin 2 (Class I0 matched to the flat areas, Class I1 to the most part of the area, and Class I2 to the hilly terrigenous area. Higher-intensity classes, which are likely to be landslide areas, were not considered in this extrapolation operation since it refers to "no landslide areas"). The output Intensity map from these operations consisted of five classes (I0 negligible, I1 slight, I2 medium, I3 high, and I4 very high).

Regarding the "known landslides", which are 12 translational slide and flow types located in the SW portion of Volterra city (Figure 5), their morphometric parameters, i.e., depths, extents and volumes, were derived from GEOPROGETTI [41] and the landslide intensity was evaluated in four classes, already defined in Catani et al. [7]: I1 $\left(\mathrm{V}<10^{3} \mathrm{~m}^{3}\right)$, I2 $\left(10^{3} \mathrm{~m}^{3} \leq \mathrm{V}<5 \times 10^{4} \mathrm{~m}^{3}\right)$, I3 $\left(5 \times 10^{4} \mathrm{~m}^{3} \leq \mathrm{V}<106 \mathrm{~m}^{3}\right)$, I4 $\left(\mathrm{V} \geq 106 \mathrm{~m}^{3}\right)$. Based on this log-frequency distribution classification, the mapped landslides were assessed as classes I3 and I4 (Figure 5).

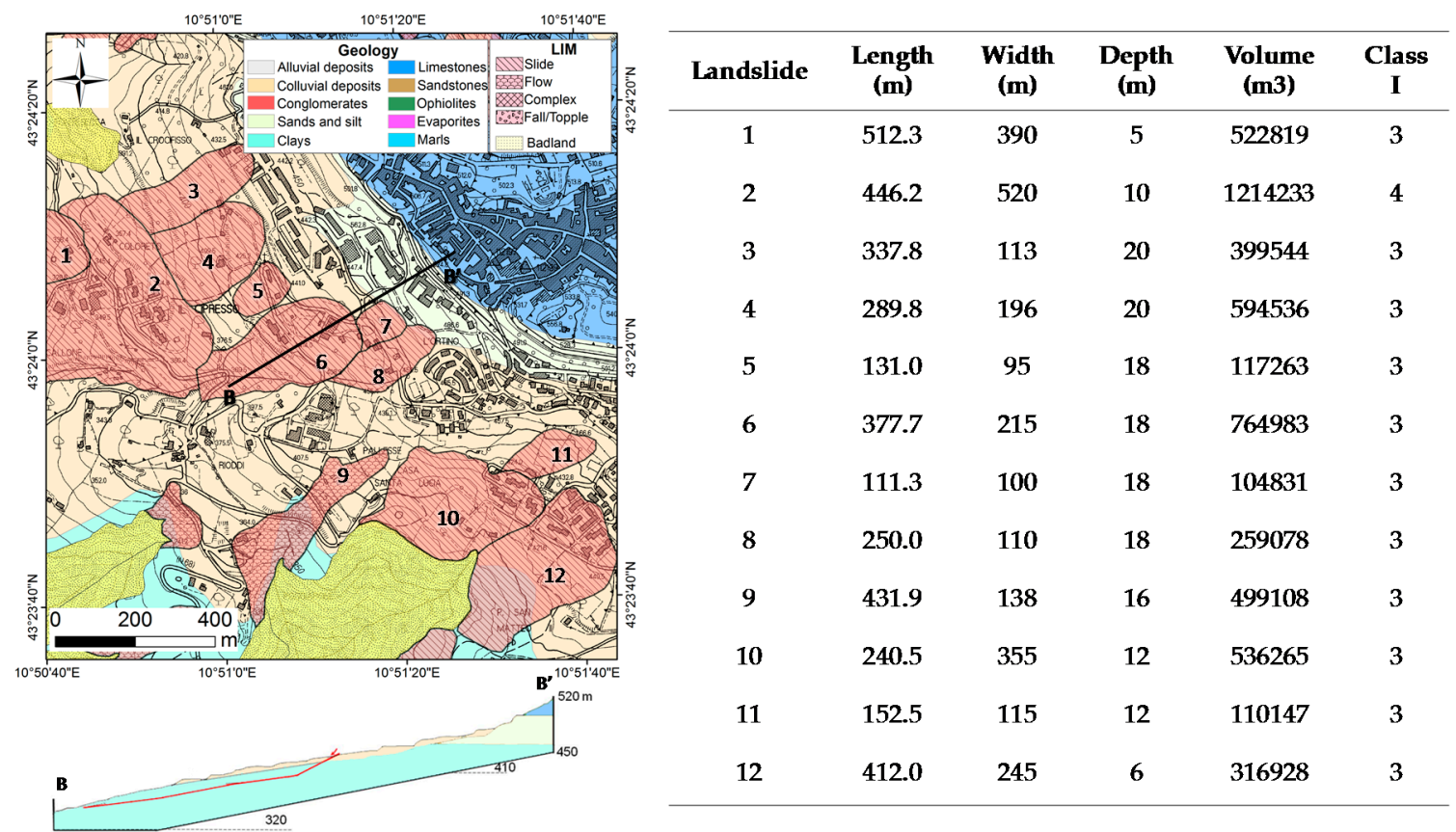

Figure 5. Close-up area whose location is shown in Figure 4: (Left) location of 12 known landslides overlapped on geological map and one related geological section; and (Right) table of morphometric parameters of known landslides and I Class. 
2. The preliminary I map derived from the first phase was then enhanced in second phase using PSI data. The second phase is composed of a sequence of steps as follows:

- $\quad$ PSI LOS velocities conversion: The LOS velocities of Sentinel-1 PSI data were converted in ground velocities by means of a downslope projection $[23,26,50]$. In particular, all the PSI average yearly $\mathrm{V}_{\mathrm{LOS}}(\mathrm{mm} /$ year) were projected into the same direction of the steepest slope through a correction factor $(\mathrm{C})$, in order to determine the "real" velocity (not the one measured in the LOS direction, but the one occurring in the landslide direction). The relation between the "real" velocity in the direction of the landslide direction $\left(\mathrm{V}_{\mathrm{SLOPE}}\right)$, the measured velocity in the satellite $\operatorname{LOS}\left(\mathrm{V}_{\mathrm{LOS}}\right)$ and the correction factor is given by the equation: $\mathrm{V}_{\mathrm{SLOPE}}=\mathrm{V}_{\mathrm{LOS}} / \mathrm{C}$, where the correction factor $C$ depends on the topographic parameters (slope and aspect map of the area) and satellite-dependent parameters (LOS directional cosines) [50]. The $\mathrm{V}_{\text {SLOPE }}$ values were taken as absolute values ( $\mathrm{V}_{\mathrm{SLOPE}-\mathrm{ABS}}$ ) and no longer referred to as movements away from/towards the satellite. This procedure allows providing $\mathrm{V}_{\text {SLOPE-ABS }}$ values with stability thresholds set to $2 \mathrm{~mm}$ /year, according to the standard deviation of the PSI population and in agreement with similar choice already tested in scientific literature $[22,23,50]$. The $\mathrm{V}_{\text {SLOPE-ABS }}$ conversion allows merging ascending and descending geometries, thus avoiding misinterpretation and underestimation of the motion due to combination of topography and satellite acquisition orbit (i.e., layover and shadowing problems) and obtaining absolute velocity values corresponding to movement rates along the local steepest slope, which is assumed to be the most likely motion direction.

- Correlation of PSI V VLOPE-ABS velocities with Intensity class: The PSI V VLOPE-ABS velocities are exploited for the evaluation of intensity in four different classes: "ND" (not defined), "negligible", "extremely slow" and "very slow". These classes are defined according to the velocity scale of Cruden and Varnes [44] and IUGS-WGL [49]: velocity class "very slow" refers to PSI targets

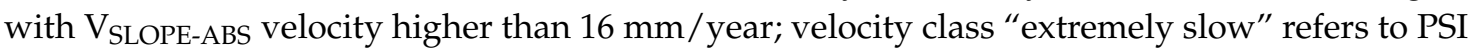
targets with $\mathrm{V}_{\text {SLOPE-ABS }}$ velocity between 2 and $16 \mathrm{~mm}$ /year); PSI targets with by $\mathrm{V}_{\text {SLOPE-ABS }}$ velocity lower than $2 \mathrm{~mm}$ /year are classified as "negligible". "ND" class is for no data, due to the point-wise discrete distribution of PSI data (Figure 6).

- Conversion of PSI $V_{S L O P E-A B S}$ into raster map: The PSI V VLOPE-ABS velocities are converted in raster format with $20 \mathrm{~m}$ cell size in a GIS environment.

- Conversion of Preliminary I map into discrete centroids: The preliminary I map is converted to a point-grid of points positioned at the centers of the starting raster map cells (centroids). This last operation allows converging the I value information of the previously raster-converted PSI data to the centroids of the Preliminary I map. Therefore, two I values, the one from I map point-grid and the one from PSI raster, are concurrently present in the attribute table of the preliminary I map centroids.

- Use of MATRIX 1 for final Intensity value $I_{f}$ : The final intensity value $\left(\mathrm{I}_{\mathrm{f}}\right)$ is chosen according to the contingency matrix shown in Table 3, which consists of cell grids, whose inputs are I values from PSI V VLOPE-ABS and from the preliminary I map, and whose outputs are five Intensity classes.

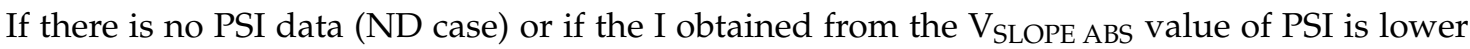
than the one derived from the preliminary I map, then the intensity class of the latter has been maintained as $I_{f}$. If the I value class obtained from the $V_{\text {SLOPE ABS }}$ of the PSI data is higher than the preliminary I map class, then the intensity class $I_{\mathrm{f}}$ has been changed, assigning it the highest value obtained from the PSI data.

- Conversion of centroids with $I_{f}$ values into final Intensity map: The centroid points were converted into raster map surface using the new value $\mathrm{I}_{\mathrm{f}}$ as value field of the map with a resolution cell of $20 \times 20 \mathrm{~m}$. The final output represents the Intensity map of ground movements over the study area (Figure 7) to be considered for the Specific Risk computation. 


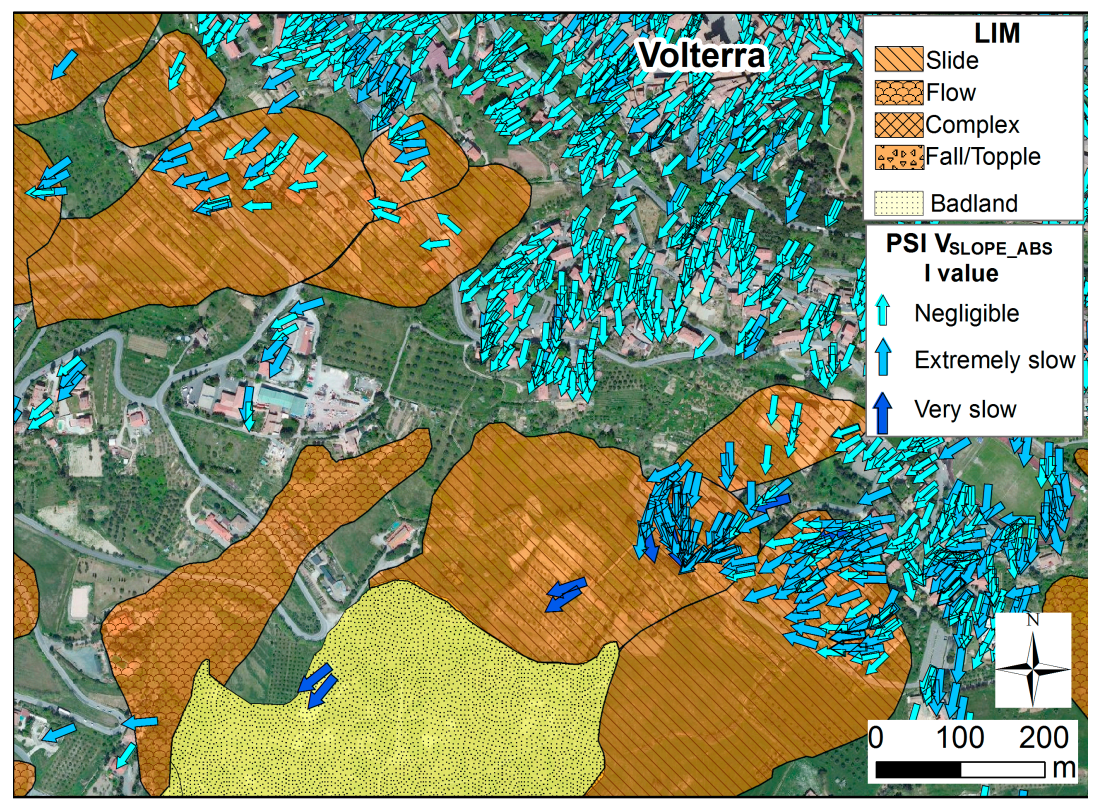

Figure 6. Distribution of PSI V SLOPE-ABS velocities with Intensity value (I value) on known landslides SW Volterra city center.

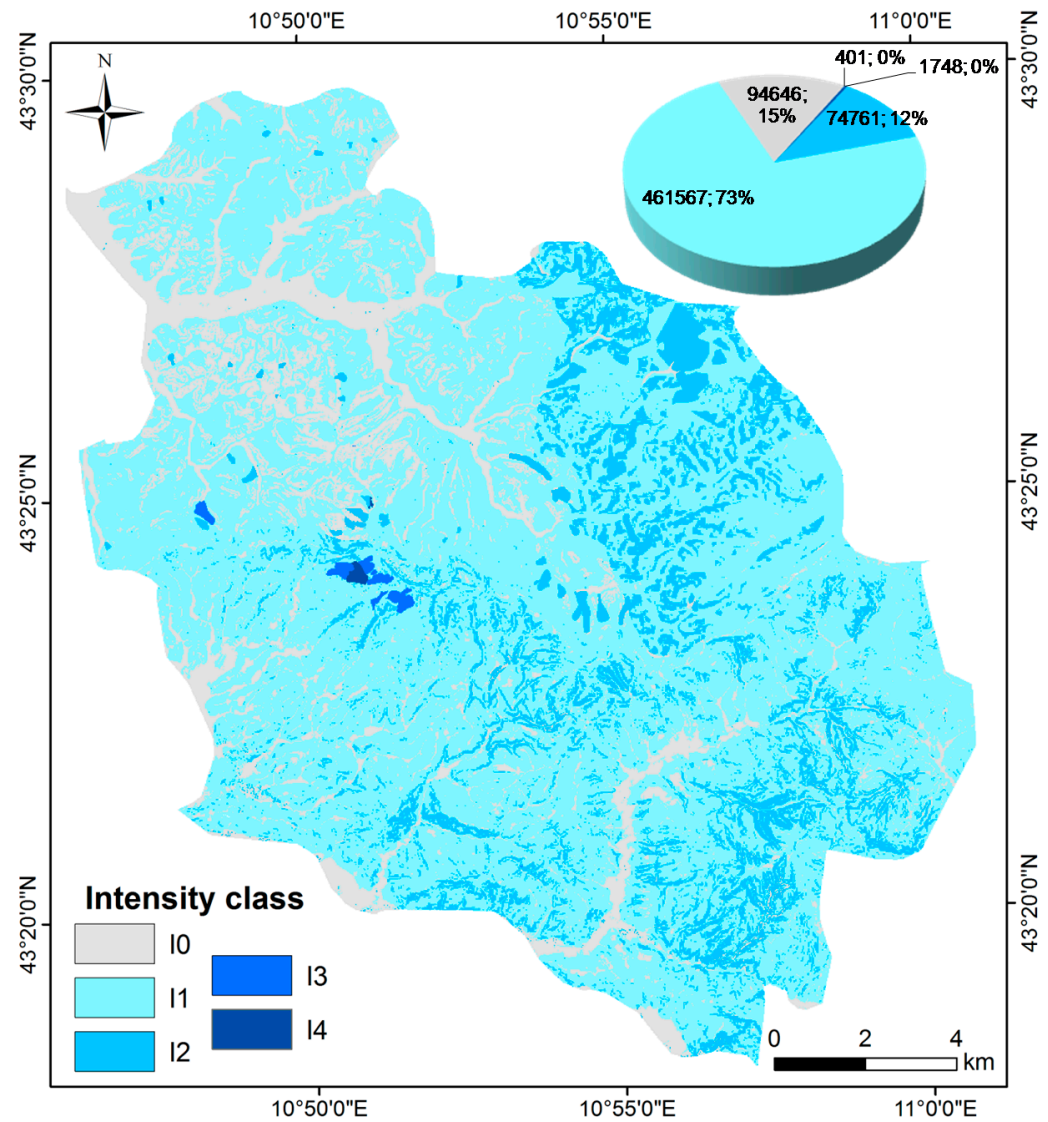

Figure 7. Intensity map $\left(\mathrm{I}_{\mathrm{f}}\right)$ of ground movements improved with PSI Sentinel-1 data. The pie chart shows number of pixels and related percentage for each Intensity class: The $0 \%$ percentages of Intensity classes I 3 and I4 actually correspond to decimal values 0.001 and 0.003 , respectively. 
Table 3. Contingency matrix (MATRIX 1), which combines I values from PSI V $\mathrm{SLOPE}_{\text {-ABS }}$ and from the Preliminary I map for deriving five final Intensity classes $I_{f}$.

\begin{tabular}{cccccc}
\hline & \multicolumn{4}{c}{ I Value from PSI Data } \\
\cline { 2 - 6 } & & ND 0 & Negligible 1 & Extremely Slow 2 & Very Slow 3 \\
\hline \multirow{3}{*}{ I Value from } & 0 & 0 & 1 & 2 & 3 \\
Preliminary I Map & 1 & 1 & 1 & 2 & 3 \\
& 2 & 2 & 2 & 2 & 3 \\
& 3 & 3 & 3 & 3 & 3 \\
& 4 & 4 & 4 & 4 & 4 \\
\hline
\end{tabular}

\subsection{Elements at Risk and Their Vulnerability}

For the estimation of the vulnerability, we used a simple approach based on the inferred relationship between the intensity of ground movements of expected landslides, and the potential damage a landslide would cause in a given area due to the presence of different elements at risk.

The vector database of buildings and linear elements (roads or other communication paths) was merged with the polygons of the second-level CORINE Land cover map for the evaluation of elements at risk.

This element at risk map was converted, within GIS system, firstly into raster surface with $20 \mathrm{~m}$ cell size and then into points corresponding to the centroids of the pixel cells of the raster.

At this point, the quantification of the vulnerability was performed by assigning a percentage of expected damage for each degree of ground movement intensity to the centroids, for each type of element at risk. Since the intensity classes are 5, we will have five different values V(I) for each category of element.

The chosen $\mathrm{V}$ values are average and do not take into account the differences between the construction type of buildings, nor their maintenance status. For this reason, the provided vulnerability data are sufficient for a municipal risk assessment, unless not suitable for more detailed analysis.

Table 4 shows the expected damage to buildings, roads and population in terms of vulnerability (V) affected by ground motions of different intensity (I0-I4).

It is worth noting that the $\mathrm{V}$ values have been chosen by qualitatively referring to the damage that a potential ground movement due to landslide may cause to buildings and manufactures.

In particular, residential buildings where people live and touristic complex areas are characterized by the highest loss values, being usually located in areas of high environmental/cultural interest and at high risk due to natural events such as floods and landslides [5,32].

According to the adopted criteria, it can be noticed that no building typology is supposed to suffer a $100 \%$ potential loss $(V=100)$, even in case of occurrence of an event of high intensity $(I=I 4)$, since all the investigated and mapped landslides in the study area are slow-moving phenomena. Differently, for roads and railways a vulnerability value of 100 was attributed in case of maximum intensity event, since even a slow-moving landslide can determine interruption of road/rail network.

Regarding land use coverage, it can be seen that the maximum loss values were allocated to crops and vineyards or olive groves, as the occurrence of landslide phenomenon would cause huge production damages [34].

Table 4. Vulnerability values (V) in percent of each element at risk type for ground motions of different intensity.

\begin{tabular}{ccccccc}
\hline Code & Description & V0 (I = I0) & V1 (I = I1) & V2 (I = I2) & V3 (I = I3) & V4 (I = I4) \\
\hline A & Public/administrative building & 3 & 5 & 20 & 30 & 60 \\
B & Industrial/Commercial building & 3 & 5 & 15 & 30 & 50 \\
C & Building under construction & 3 & 5 & 10 & 30 & 40 \\
D & Abandoned/Ruined building & 3 & 5 & 10 & 20 & 40 \\
E & Power station/Power shed & 3 & 5 & 15 & 50 \\
\hline
\end{tabular}


Table 4. Cont

\begin{tabular}{|c|c|c|c|c|c|c|}
\hline Code & Description & V0 (I = I0) & V1 (I = I1) & V2 (I = I2) & V3 (I = I3) & V4 (I = I4) \\
\hline $\mathrm{F}$ & Stable/Barn/Breeding farm & 3 & 5 & 15 & 40 & 60 \\
\hline G & Not residential building & 3 & 5 & 30 & 50 & 70 \\
\hline $\mathrm{H}$ & Residential building & 3 & 5 & 60 & 60 & 80 \\
\hline $\mathrm{I}$ & Church/Religious complex & 3 & 5 & 15 & 30 & 60 \\
\hline $\mathrm{L}$ & Campground/Touristic complex & 3 & 5 & 20 & 50 & 80 \\
\hline M & Dump/Landfill & 3 & 5 & 10 & 20 & 40 \\
\hline $\mathrm{N}$ & Croplands & 3 & 5 & 30 & 40 & 70 \\
\hline $\mathrm{O}$ & Vineyards and olive groves & 3 & 5 & 40 & 50 & 70 \\
\hline $\mathrm{P}$ & Grassland/pastures & 3 & 5 & 10 & 20 & 40 \\
\hline Q & Wood & 3 & 5 & 10 & 20 & 40 \\
\hline $\mathrm{R}$ & Shrubs/herbaceous & 3 & 5 & 10 & 20 & 30 \\
\hline$S$ & Agricultural/Natural areas & 3 & 5 & 30 & 40 & 50 \\
\hline $\mathrm{T}$ & State highway/Tollroad & 3 & 5 & 30 & 50 & 80 \\
\hline $\mathrm{U}$ & Provincial highway & 3 & 5 & 40 & 60 & 100 \\
\hline $\mathrm{V}$ & Provincial/Municipal roads & 3 & 5 & 50 & 80 & 100 \\
\hline W & Local roads/Private roads & 3 & 5 & 60 & 80 & 100 \\
\hline $\mathrm{Z}$ & Railways & 3 & 5 & 60 & 80 & 100 \\
\hline
\end{tabular}

Once an intensity value and a consequent vulnerability value have been attributed to each centroid of the Element at risk map according to Table 4, the points have been transformed into a raster map with a resolution of $20 \mathrm{~m} \times 20 \mathrm{~m}$, where pixels have a $\mathrm{V}$ value, ranging from 0 to 100 . To homogenize and match the vulnerability map to the previously obtained $\mathrm{H}$ map, all values were grouped and reclassified in five classes, as shown in Figure 8.

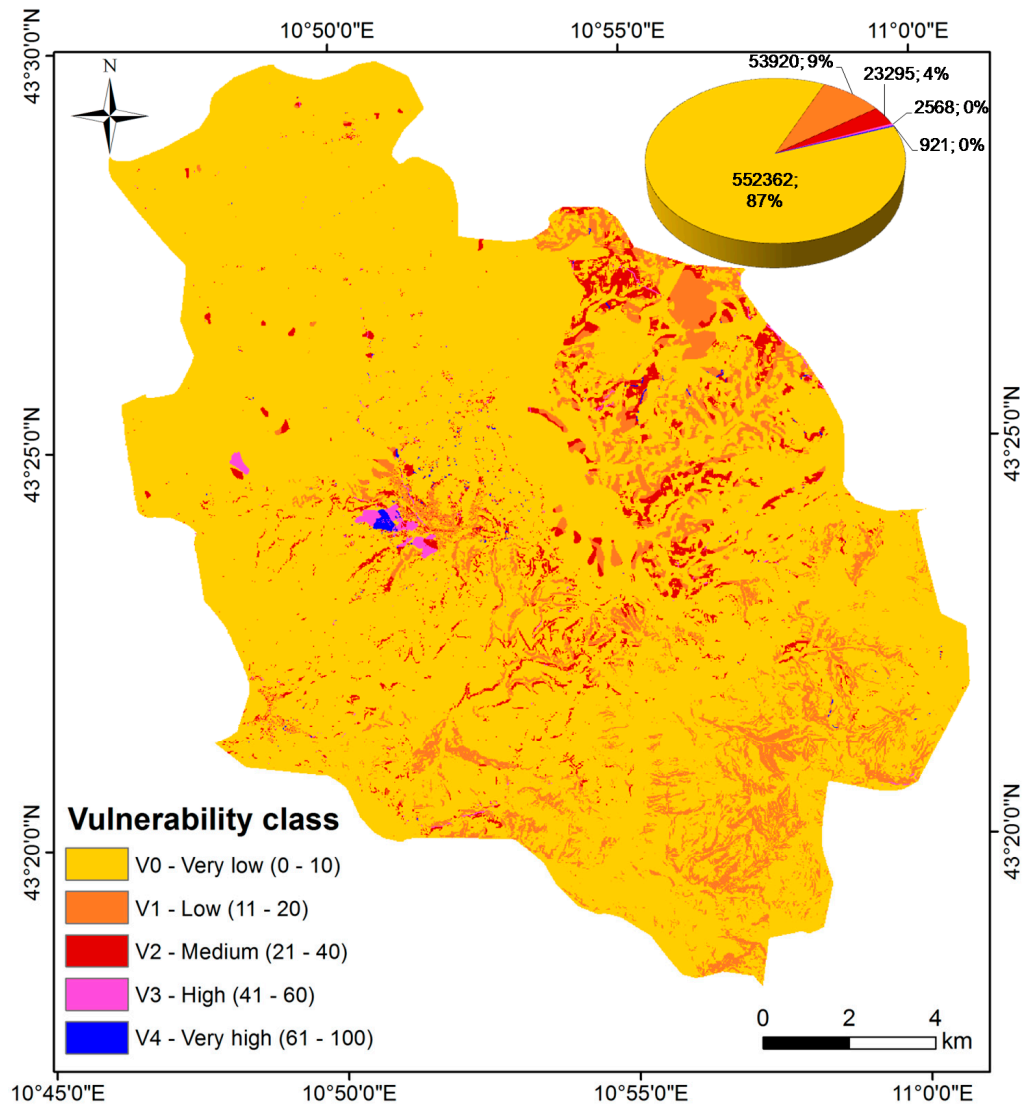

Figure 8. Vulnerability map. The pie chart shows number of pixels and related percentage for each Intensity class. The $0 \%$ percentages of Intensity classes V3 and V4 actually correspond to decimal values 0.004 and 0.001 , respectively. 


\subsection{Specific Risk}

The integration of the results from the different maps leads to the elaboration of specific risk mapping, since the specific risk $\left(R_{s}\right)$ is based on $\mathrm{H}$ and $\mathrm{V}$ components that are function of $\mathrm{E}$ and $\mathrm{I}$, according to the equation: $R_{s}=H(I) \times V(I, E)$.

In particular, the specific risk assessment $\left(R_{s}\right)$ was obtained by using the contingency matrix (MATRIX 2) shown in Table 5, which cross-checks the $\mathrm{H}$ classes of spatial hazard with the $\mathrm{V}$ classes of expected loss.

Table 5. Contingency matrix MATRIX 2 for deriving Specific Risk and Specific risk map over the study area. Cell numbers are associated to the Specific Risk class and then referred as R1-R5.

\begin{tabular}{llccccc}
\hline & & \multicolumn{5}{c}{ Vulnerability Class } \\
\cline { 3 - 7 } & & V0 & V1 & V2 & V3 & V4 \\
\hline \multirow{5}{*}{ Spatial Hazard Class } & H0 & 1 & 1 & 1 & 2 & 2 \\
& H1 & 1 & 2 & 3 & 3 & 4 \\
& H2 & 1 & 3 & 3 & 4 & 4 \\
& H3 & 2 & 3 & 4 & 4 & 5 \\
& H4 & 2 & 4 & 4 & 5 & 5 \\
\hline
\end{tabular}

The square matrix permitted deriving five classes of $R_{s}$. For the $R_{s}$ cell assignment, the highest $\mathrm{H}$ or $\mathrm{V}$ class value has always been considered to take into account the most cautionary situation. The specific risk is higher where most potential ground movements due to landslides, i.e., high $\mathrm{H}$ classes are present, whereas it decreases in areas characterized by lower hazard and lower vulnerability.

The derived risk index $R_{S}$ is based on five classes of specific Risk, named R1-R5 (very low, low, medium, high, and very high) based on cell-grid numbers of the matrix (Figure 9). The resulting map is shown in next section.

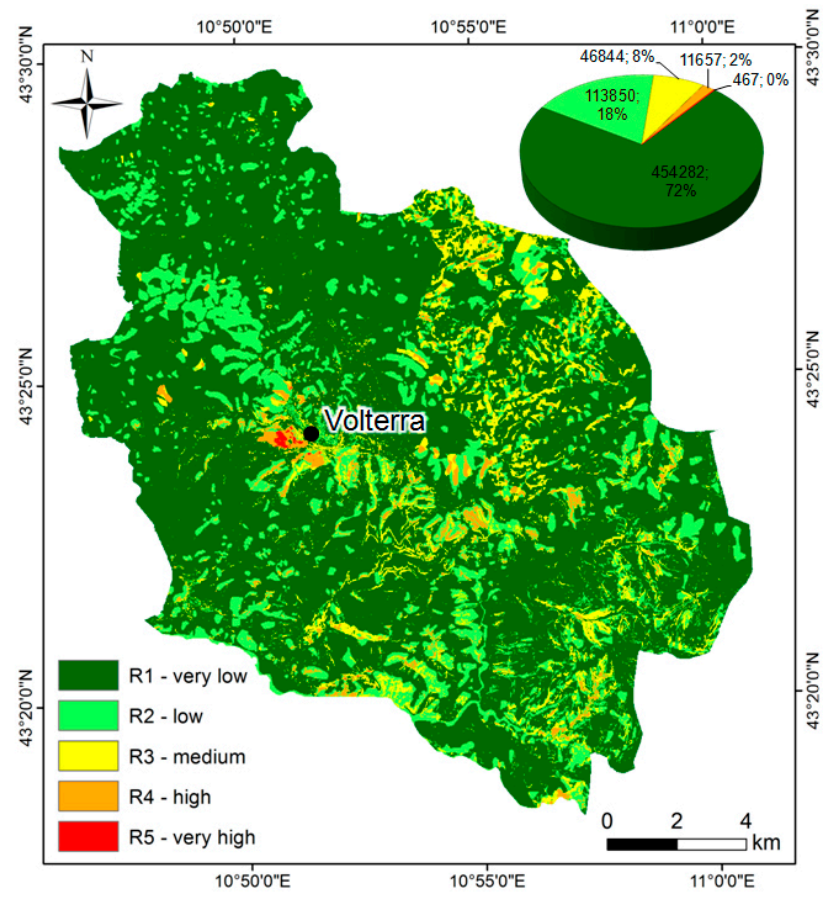

Figure 9. The pie chart shows the number of pixels and related percentage for each $\mathrm{R}_{\mathrm{S}}$ class. The $0 \%$ percentage of Specific Risk class R4 actually corresponds to a decimal value of 0.001 . 


\section{Results}

The output Rs map derived from the matrix is shown in Figure 8. The map is a raster surface with 20 cell size resolution based on five classes of specific risk.

The pie chart in Figure 8 presents the pixel value percentages of the $R_{s}$ map, revealing that $72 \%$ (454,282 pixels) is in R1 class and 18\% (113,850 pixels) in R2 class, respectively, corresponding to very low and low specific risk. The highest specific risk, represented by class R5, is almost only localized in the southwestern portion of Volterra city, where vulnerability is high due to the urban fabric and the presence of mapped landslides characterized by the highest intensity of ground motion.

This work allows evaluating the spatial landslide hazard, intensity and vulnerability at basin scale and then combines them for the qualitative assessment of the landslide "specific risk" on a sample area, by exploiting various thematic layers and available satellite interferometric radar data.

In particular, in this work we propose a new approach, tested over an area extended up about $250 \mathrm{~km}^{2}$, for producing a map of specific risk, supported by the use of recent satellite SENTINEL-1 PSI data acquired in recent time period 2014-2017, implemented in a GIS environment.

PSI measurements are used for updating the LIM (Landslide Inventory map) and for enhancing the related intensity map of the study area. The use of PSI data referred to the intensity of landslides has already been tested in scientific community for defining an intensity scale in terms of ground motion [27-29]. Thus, in this work, we exploited the PSI-derived ground rates for estimating the landslide intensity and consequently for evaluating the vulnerability over the whole study area. In particular, Sentinel-1 PSI data support the creation of the intensity map using a contingency matrix (Table 3), allowing the modification of $9 \%$ of the I value of pixels from the preliminary I map.

The determination of landslide specific risk as "expected damage" provides for the parameterization and the combination of a number of factors of socio-economic nature and geological environment, the valuation of which often requires interaction of different skills and expertise (geologists, engineers, planners, administrators, etc.). The three sub-components of risk, i.e., hazard, vulnerability and value of elements at risk, can therefore be determined with a different level of detail, depending on the skills of the operators and on the availability of the environmental information.

The susceptibility map of the study area, based on the spatial hazard classification according to the Italian Regional laws and provided within the strategic environmental plan of the Volterra municipality [38] reveals that the highest geomorphological susceptibility classes $\mathrm{H} 4$ and $\mathrm{H} 3$ account for $2 \%$ and $43 \%$, respectively, of the total area (Figure 4 ). They correspond to the areas characterized by erosive processes (badlands) and mass movement occurrences (landslides) as mapped in Figure 3a.

The intensity map of the study area shows that the highest intensity of ground movements is located nearby Volterra city, where PSI measures recorded the maximum velocity rates up to about 15-20 mm/year corresponding to translational landslides on clays and shallow colluvial debris. The most part of the study area falls in class I1 (low intensity) and class I0 (very low), accounting respectively for $15 \%$ and $73 \%$ of the total spatial extent (Figure 7 ).

The vulnerability map of the Volterra municipality that relies on the intensity classes and elements at risk types reveals that the $87 \%$ of the area is characterized by a very low value of vulnerability (V0), whereas the highest values V3 and V4 are basically localized in the S-SW portion of Volterra city (Figure 8).

The $R_{s}$ map shows that many areas characterized by landslides and badlands fall in class R2 (low) due to the absence of vulnerable elements at risk (Figure 9). Classes R4 and R5, corresponding to high and very high $R_{S}$ values, only account for $2 \%$ of the total area: they are localized in some areas S-SE of Volterra city, where some mapped phenomena involve the road network and various residential and touristic structures, and on the S-SW portion of Volterra city where vulnerability is high due to the urban fabric and the presence of mapped landslides characterized by the highest intensity of ground motion. Overall, it can be noted that the mapping of areas with higher $R_{\mathrm{s}}$ primarily relies on intensity zonation since the rates of ground movements categorized as intensity are included within the hazard map (for the LIM) and within the computation of the vulnerability map (for the intensity of potential events affecting elements at risk). 


\section{Discussion}

In this work, the specific risk map at municipal scale in Volterra area was produced by the evaluation of each risk sub-component, i.e., hazard, intensity, and vulnerability, of the exposed elements at risk.

The used spatial hazard map was the one included within the strategic environmental Plan of the Volterra municipality, relying on the LIM as well as on geomorphic and lithological features of the territory. The LIM provided by the Volterra municipality authority was firstly checked and improved by means of radar- and photo-interpretation combined with some field observations. In this case, monoscopic photo-interpretation of recent aerial photos was used, as considered sufficiently appropriate for the scale of investigation. Nevertheless, for higher level of detail or future in-depth analysis, the stereoscopic photo-interpretation of optical images would be recommended since it better allows the recognition of single geomorphologic indicators, soil erosion or anomalies in vegetation coverage, reaching a higher precision. Moreover, PSI velocity rates and in situ checks permitted to support the delineation of the geometry of some unstable areas. Unfortunately, PSI data show a low density (14 PSI targets $/ \mathrm{km}^{2}$ ) due to extensive presence of crops and vegetation across the area, so it is worth to highlight that they permit to enhance boundaries and activity of LIM on almost exclusively urban areas (Volterra and Saline di Volterra) and surroundings. Only $5 \%$ of the total amount of mapped landslides (60 phenomena among a total number of 1140 landslides) was updated in boundaries.

The intensity map was produced over the whole study area for both landslides and "no landslide" areas, relying on the predisposing factors that mainly influence volume and velocity (lithology, slope and curvature), on morphometric parameters of known landslides, as well as on velocity rates derived from PSI data. To obtain a more homogeneous assignment of intensity value over the whole area, the use of "slope units" [51] would be a good choice as future enhancement of the procedure.

The used method for specific risk analysis is a qualitative approach, as it is based on a system of contingency matrices to derive classes rather than numerical values. Nevertheless, despite its minor precision with respect to a complete QRA, the proposed method is more intelligible and readable by public local authorities for urban and environmental planning purposes over wide area e.g., at municipal level, so it would be effective to support administrative users with updated basic information on risk evaluation on a given area. Moreover, the methodology was designed as a reproducible GIS-procedure that can be easily updated with new and more accurate information. This is particularly useful because risk factors are characterized by short-term variations and can be rapidly mapped and evaluated through remotely sensed data, which nowadays are readily available and have a frequent temporal sampling.

Overall, the limitations of the approach are due to the intrinsic limitation of SAR data: firstly, applicability of the PSI technique is limited to extremely slow and very slow movements (vel. $<16 \mathrm{~mm}$ /year and $16 \mathrm{~mm} /$ year $\leq$ vel. $<1.6 \mathrm{~m} /$ year, respectively) because of the signal wavelength and satellite acquisition parameters [32]; and, secondly, PSI ground measurements recorded on single targets may not be indicative of landslide processes, but potentially due to single instable structures (i.e., building settlement), even if this second possibility is less likely to be, given the investigation on known landslide-affected and landslide-prone areas.

On the one hand, as qualitative approach of specific risk evaluation, the proposed procedure is more feasible at medium scale. On the other hand, at detailed scale with higher spatial resolution, the exploitation of PSI data for ground motion intensity would allow to better refine the intensity zonation with an improved accuracy and spatial resolution. The use of SAR data acquired by different microwave bands (i.e., X-band or in L-band) with different PSI targets density would lead to the velocity assessment of a higher number of pixels within the creation of the I map point-grid, providing an improved precision and thus a more accurate intensity and specific risk mapping. In particular, L-band would increase the PSI density on rural areas due to the high penetration capacity in vegetation coverage in this microwave band; conversely, $\mathrm{X}$-band data would work well on urbanized areas since 
in this band many coherent targets can be identified on site-specific built-up areas and a high the number of PS benchmarks that show up on housetops and facades of buildings is higher compared to medium resolution data, enabling a more site-specific investigation on built-up areas. Moreover, the proposed GIS-based procedure does not include a validation of the approach. Thus, as further future improvement, the possible availability of further recent event inventories would be useful to test the effectiveness of the hazard and intensity mapping of the area and the validity of our specific risk assessment.

\section{Conclusions}

In this work, we presented a qualitative approach at municipal scale for producing a "specific risk" map, supported by the use of recent satellite PSI data implemented in a GIS environment. In particular, ground velocities derived from PSI measurements of SENTINEL-1 sensors in C-band in the spanning time 2014-2017 were exploited for the zonation map of the intensity of terrain motions, needed for evaluating the vulnerability over the study area.

The risk sub-components, i.e., hazard and vulnerability of elements at risk, and the final specific risk classes were assessed by means of contingency matrixes.

Results reveals that the highest specific risk in the study area is localized in the southwestern portion of Volterra city, where vulnerability is high due to the presence of roads and residential buildings within the urban fabric, as well as mapped landslides characterized by the highest intensity of ground motion.

The presented procedure could be useful to support the local authorities with updated basic information required for environmental knowledge and planning at municipal level. Moreover, the methodology is easily repeatable to other case studies and it could be handled by using also different SAR sensors in L- or X-band.

Acknowledgments: Authors would like to thank GEOPROGETTI Company (geologists Francesca Franchi and Emilio Pistilli) for making the geological and geotechnical data on Volterra available. Authors would also like to thank Chiara Colarusso greatly helped to handle available data of Volterra municipality in GIS within her Master degree work. SAR data were processed by TRE ALTAMIRA S.r.l. through SqueeSAR ${ }^{\text {TM }}$ technique.

Author Contributions: Silvia Bianchini conceived and designed the research, carried out data interpretation and wrote the manuscript; Lorenzo Solari contributed to writing the paper and improving the quality of the work; and Nicola Casagli coordinated the project work.

Conflicts of Interest: The authors declare no conflict of interest.

\section{References}

1. Carrara, A.; Crosta, G.; Frattini, P. Geomorphological and historical data in assessing landslide hazard. Earth Surf. Processes Landf. 2003, 28, 1125-1142. [CrossRef]

2. Fell, R.; Corominas, J.; Bonnard, C.; Cascini, L.; Leroi, E.; Savage, W.Z. Guidelines for landslide susceptibility, hazard and risk-zoning for land use planning. Eng. Geol. 2008, 102, 85-98. [CrossRef]

3. Van Westen, C.J.; Van Asch, T.W.; Soeters, R. Landslide hazard and risk zonation-Why is it still so difficult? Bull. Eng. Geol. Environ. 2006, 65, 167-184. [CrossRef]

4. Sassa, K.; Fukuoka, H.; Wang, F.; Wang, G. Risk Analysis and Sustainable Disaster Management; Landslides; Springer: Berlin, Germany, 2005.

5. Pellicani, R.; Van Westen, C.J.; Spilotro, G. Assessing landslide exposure in areas with limited landslide information. Landslides 2014, 11, 463-480. [CrossRef]

6. Glade, T.; Crozier, M. The nature of landslide hazard impact. In Landslide Hazard and Risk; Glade, T., Anderson, M., Crozier, M., Eds.; Wiley: Chichester, UK, 2005; pp. 43-74.

7. Catani, F.; Casagli, N.; Ermini, L.; Righini, G.; Menduni, G. Landslide hazard and risk mapping at catchment scale in the Arno River basin. Landslides 2005, 2, 329-342. [CrossRef]

8. Varnes, D.J. Landslide Hazard Zonation: A Review of Principles and Practice; UNESCO: Paris, France, 1984; pp. 3-63. ISBN 92-3-101895-7. 
9. Dai, F.C.; Lee, C.F.; Ngai, Y.Y. Landslide risk assessment and management: An overview. Eng. Geol. 2002, 64, 65-87. [CrossRef]

10. Cruden, D.M.; Fell, R. Landslide risk assessment. In Proceedings of the International Workshop on Landslide Risk Assessment, Honolulu, HI, USA, 19-21 February 1997; Cruden, F., Ed.; Balkema: Rotterdam, The Netherlands, 1997.

11. Van Westen, C.J.; Castellanos, E.; Kuriakose, S.L. Spatial data for landslide susceptibility, hazard, and vulnerability assessment: An overview. Eng. Geol. 2008, 102, 112-131. [CrossRef]

12. Wang, H.B.; Wu, S.R.; Shi, J.S.; Li, B. Qualitative hazard and risk assessment of landslides: A practical framework for a case study in China. Nat. Hazards 2013, 69, 1281-1294. [CrossRef]

13. Fell, R. Landslide Risk Management Concepts and Guidelines-Australian Geomechanics Society Sub-Committee on Landslide Risk Management; International Union of Geological Sciences: Cardiff, UK, 2000; pp. 51-93.

14. Lee, E.M.; Jones, D.K. Landslide Risk Assessment; Thomas Telford Ltd.: London, UK, 2004.

15. Bell, R.; Glade, T. Quantitative risk analysis for landslides? Examples from Bíldudalur, NW-Iceland. Nat. Hazards Earth Syst. Sci. 2004, 4, 117-131. [CrossRef]

16. Huabin, W.; Gangjun, L.; Weiya, X.; Gonghui, W. GIS-based landslide hazard assessment: An overview. Prog. Phys. Geogr. 2005, 29, 548-567. [CrossRef]

17. Bianchini, S.; Del Soldato, M.; Solari, L.; Nolesini, T.; Pratesi, F.; Moretti, S. Badland susceptibility assessment in Volterra municipality (Tuscany, Italy) by means of GIS and statistical analysis. Environ. Earth Sci. 2016, 75. [CrossRef]

18. Ferretti, A.; Prati, C.; Rocca, F. Permanent Scatterers in SAR Interferometry. IEEE Trans. Geosci. Remote Sens. 2001, 39, 8-20. [CrossRef]

19. Hooper, A.; Zebker, H.A.; Segall, P.; Kampes, B. A new method for measuring deformation on volcanoes and other natural terrains using InSAR persistent scatterers. Geophys. Res. Lett. 2004, 31. [CrossRef]

20. Berardino, P.; Fornaro, G.; Lanari, R.; Sansosti, E. A new algorithm for surface deformation monitoring based on small baseline differential SAR interferograms. IEEE Trans. Geosci. Remote Sens. 2002, 40, 2375-2383. [CrossRef]

21. Arnaud, A.; Adam, N.; Hanssen, R.; Inglada, J.; Duro, J.; Closa, J.; Eineder, M. ASAR ERS interferometric phase continuity. In Proceedings of the IEEE International Geoscience and Remote Sensing Symposium: Learning from Earth's Shapes and Colours, Toulouse, France, 21-25 July 2003.

22. Notti, D.; Herrera, G.; Bianchini, S.; Meisina, C.; García-Davalillo, J.C.; Zucca, F. A methodology for improving landslide PSI data analysis. Int. J. Remote Sens. 2014, 35. [CrossRef]

23. Cascini, L.; Fornaro, G.; Peduto, D. Advanced low- and full-resolution DInSAR map generation for slow-moving landslide analysis at different scales. Eng. Geol. 2010, 112, 29-42. [CrossRef]

24. Cigna, F.; Del Ventisette, C.; Liguori, V.; Casagli, N. Advanced radar-interpretation of InSAR time series for mapping and characterization of geological processes. Nat. Hazards Earth Syst. Sci. 2011, 11, 865-881. [CrossRef]

25. Liao, M.; Tang, J.; Wang, T.; Balz, T.; Zhang, L. Landslide monitoring with high-resolution SAR data in the Three Gorges region. Sci. China Earth Sci. 2012, 55, 590-601. [CrossRef]

26. Herrera, G.; Gutiérrez, F.; Garcí-Davalillo, J.C.; Guerrero, J.; Galve, J.P.; Fernández-Morodo, J.A.; Cooksley, G. Multi-sensor advanced DInSAR monitoring of very slow landslides: The Tena valley case study (central Spanish Pyrenees). Remote Sens. Environ. 2013, 128, 31-43. [CrossRef]

27. Bianchini, S.; Cigna, F.; Righini, G.; Proietti, C.; Casagli, N. Landslide HotSpot Mapping by means of Persistent Scatterer Interferometry. Environ. Earth Sci. 2012, 67, 1155-1172. [CrossRef]

28. Lu, P.; Casagli, N.; Catani, F.; Tofani, V. Persistent Scatterers Interferometry Hotspot and Cluster Analysis (PSI-HCA) for detection of extremely slow-moving landslides. Int. J. Remote Sens. 2012, 33, 466-489. [CrossRef]

29. Righini, G.; Pancioli, V.; Casagli, N. Updating landslide inventory maps using Persistent Scatterer Interferometry (PSI). Int. J. Remote Sens. 2012, 33, 2068-2096. [CrossRef]

30. Cigna, F.; Bianchini, S.; Casagli, N. How to assess landslide activity and intensity with Persistent Scatterer Interferometry (PSI): The PSI-based matrix approach. Landslides 2013, 10, 267-283. [CrossRef]

31. Raspini, F.; Bardi, F.; Bianchini, S.; Ciampalini, A.; Ventisette, C.; Farina, P.; Ferrigno, F.; Solari, L.; Casagli, N. The contribution of satellite SAR-derived displacement measurements in landslide risk management practices. Nat. Hazards 2017, 1, 327-351. [CrossRef] 
32. Ciampalini, A.; Raspini, F.; Lagomarsino, D.; Catani, F.; Casagli, N. Landslide susceptibility map refinement using PSInSAR data. Remote Sens. Environ. 2016, 184, 302-315. [CrossRef]

33. Piacentini, D.; Devoto, S.; Mantovani, M.; Pasuto, A.; Prampolini, M.; Soldati, M. Landslide susceptibility modeling assisted by Persistent Scatterers Interferometry (PSI): An example from the northwestern coast of Malta. Nat. Hazards 2015, 78, 681-697. [CrossRef]

34. Tofani, V. Ricerca e Sperimentazione di Metodologie per la Valutazione del Rischio da Frana a Scala di Bacino. Ph.D. Thesis, University of Florence, Florence, Italy, 2006.

35. Annoni, A.; Perdigao, V. Technical and Methodological Guide for Updating CORINE Land Cover Database; European Commission, EUR 17288EN; Space Application Institute of Joint Research Centre: Ispra, Italy, 1997.

36. Giannini, E.; Lazzarotto, A.; Signorini, R. Lineamenti di stratigrafia e di tettonica. In La Toscana Meridionale. Rend. Soc. Ital. Miner. Petrol. 1971, 27, 33-68.

37. Bianchini, S.; Pratesi, F.; Nolesini, T.; Casagli, N. Building deformation assessment by means of persistent scatterer interferometry analysis on a landslide-affected area: The Volterra (Italy) case study. Remote Sens. 2015, 7, 4678-4701. [CrossRef]

38. Pascucci, V.; Merlini, S.; Martini, I.P. Seismic stratigraphy of the Miocene-Pleistocene sedimentary basins of the Northern Tyrrhenian Sea and western Tuscany (Italy). Basin Res. 1999, 11, 337-356. [CrossRef]

39. Costantini, A.; Lazzarotto, A.; Mazzanti, R.; Mazzei, R.; Salvatorini, G.F.; Sandrelli, F. Note Illustrative della Carta Geologica d'Italia, alla scala 1:50.000, Foglio 285, Volterra. Serv. Geol. Ital. 2002, 285, 152-153.

40. Tarquini, S.; Vinci, S.; Favalli, M.; Doumaz, F.; Fornaciai, A.; Nannipieri, L. Release of a 10-m-resolution DEM for the Italian territory: Comparison with global-coverage DEMs and anaglyph-mode exploration via the web. Comput. Geosci. 2012, 38, 168-170. [CrossRef]

41. GEOPROGETTI-Studio Associato Company. Indagini Geognostiche e Sismiche per L'analisi Dell'assetto Geologico e Geomorfologico del Versante Sud di Volterra; Report for the Volterra Municipality; Studio Associato Company: Volterra, Italy, 2010; Available online: http:/ / www.comune.volterra.pi.it (accessed on 28 August 2017).

42. Ferretti, A.; Fumagalli, A.; Novali, F.; Prati, C.; Rocca, F.; Rucci, A. A new algorithm for processing interferometric datastacks: SqueeSAR ${ }^{\mathrm{TM}}$. IEEE Trans. Geosci. Remote Sens. 2011, 99, 1-11.

43. Hungr, O. A model for the runout analysis of rapid flow slides, debris flows, and avalanches. Can. Geotech. J. 1995, 32, 610-623. [CrossRef]

44. Cruden, D.M.; Varnes, D.J. Landslide Types and Processes. In Landslides: Investigation and Mitigation: Sp. Rep. 247; Turner, A.K., Schuster, R.L., Eds.; Transportation Research Board, National research Council, National Academy Press: Washington, DC, USA, 1996; pp. 36-75.

45. Einstein, H.H. Special lecture: Landslide risk assessment procedure. In Proceedings of the 5th International Symposium on Landslides, Lausanne, Switzerland, 10-15 July 1988; Volume 2, pp. 1075-1090.

46. Cardinali, M.; Reichenbach, P.; Guzzetti, F.; Ardizzone, F.; Antonini, G.; Galli, M.; Salvati, P. A geomorphological approach to the estimation of landslide hazards and risks in Umbria, Central Italy. Nat. Hazards Earth Syst. Sci. 2002, 2, 57-72. [CrossRef]

47. Hungr, O. Some methods of landslide hazard intensity mapping. In Proceedings of the International Workshop on Landslide Risk Assessment, Honolulu, HI, USA, 19-21 February 1997; pp. 215-226.

48. Hungr, O. Dynamics of Rock Avalanches and Other Types of Mass Movements. Ph.D. Thesis, University of Albert, Edmonton, AB, Canada, 1981.

49. IUGS/WGL-International Union of Geological Sciences Working Group on Landslides. A suggested method for describing the rate of movement of a landslide. IAEG Bull. 1995, 52, 75-78. 
50. Bianchini, S.; Herrera, G.; Notti, D.; Mateos, R.M.; Garcia, I.; Mora, O.; Moretti, S. Landslide activity maps generation by means of Persistent Scatterer Interferometry. Remote Sens. 2013, 5, 6198-6222. [CrossRef]

51. Carrara, A.; Cardinali, M.; Detti, R.; Guzzetti, F.; Pasqui, V.; Reichenbach, P. GIS techniques and statistical models in evaluating landslide hazard. Earth Surf. Processes Landf. 1991, 16, 427-445. [CrossRef]

(C) 2017 by the authors. Licensee MDPI, Basel, Switzerland. This article is an open access article distributed under the terms and conditions of the Creative Commons Attribution (CC BY) license (http://creativecommons.org/licenses/by/4.0/). 